\title{
PROVISIONS OF POLISH LAW CONCERNING INTERVENTIONS AGAINST A FAMILY AFFECTED BY VIOLENCE - THE "BLUE CARDS" PROCEDURE, ITS LEGAL NATURE AND PRACTICAL PROBLEMS RELATED TO APPLICATION
}

\begin{abstract}
The subject matter of this article is the analysis of the provisions of the "Blue Cards" procedure initiated in the case of obtaining information about the use of domestic violence. The introduction presents the implementation thereof on the basis of the Act on Counteracting Domestic Violence. Next, the normative definition of domestic violence and family member and problems related to their practical application are discussed. The final sections illustrate the legal nature of the "Blue Cards" procedure, its course and legal steps that may be taken by a person suspected of using violence and family members affected thereby.
\end{abstract}

Keywords: violence, domestic violence, the "Blue Cards" procedure

Introduction

The Act on Counteracting Domestic Violence (the Act of 29 July 2005 on Counteracting Domestic Violence), hereinafter referred to as "u.p.p.r." or "Act on Counteracting Domestic Violence") entered into force on 21 November 2005. The legislator has noticed that the previously applied criminal law mechanisms were not sufficient to counteract the effects of, or prevent domestic violence (see: ex- 
planatory statement of the Bill on Counteracting Domestic Violence, Sejm paper No. 3639, Sejm of the $4^{\text {th }}$ term et al.). Until the Act on Counteracting Domestic Violence came into force, the basic instrument for preventing domestic violence had been the crime of abuse, regulated by Art. $207 \$ 1$ of the Criminal Code (the Act of 6 June 1997 - the Criminal Code, hereinafter referred to as „k.k.” or „Criminal Code"). At the time when the Act on Counteracting Domestic Violence was passed, the wording of the Criminal Code stipulated that anyone who abuses an immediate family member or another person, physically or mentally, in a permanent or temporary relationship of dependence to the perpetrator, shall be subject to imprisonment from 3 months to 5 years. In addition, two aggravated types were provided, i.e. abuse with extreme cruelty (Art. $207 \$ 2$ of the k.k.) and abuse resulting in the victim taking his or her own life (Article $207 \$ 3$ of the k.k.) (a third aggravated type, i.e abuse of a helpless person due to their age, mental or physical condition, was added to Art. 207 of the Criminal Code under the Act of 23 March 2017 amending the Criminal Code, the Act on Juvenile Delinquency Proceedings and the Code of Criminal Procedure).

The above criminal law structure of abuse, however, had practical weaknesses, both in juridical and factual terms. In order to make the assumption a crime of abuse has been committed, the perpetrator's activities had to be repetitive and occur over a longer period of time. Only in exceptional cases this could have been a one-off conduct and additionally, in such cases, a significant intensity of the causative act was required (cf. the Judgment of the Supreme Court of 8 February 1982, case No. II KR 5/82, Legalis 22971). Therefore, in practice, only repeatedly occurring acts (individual acts) could jointly be classified as a crime of abuse.

The very premise of abuse was also problematic due to its being an underspecified concept and thus including various types of behaviour. The behaviour catalogue is open and each time requires a thorough assessment of facts (Sosnowska, 2008 , p. 60) and, what is more, such acts can only be committed intentionally. It is disputable, however, whether it could only be committed with a direct intent (cf. e.g. the Judgment of the Supreme Court of 11 February 2003, case No. IV KKN 312/99, Legalis 58692), or also recklessness (cf. the Decision of the Supreme Court of 23 May 2017, case No. III KK 157/17, Legalis 1657909).

Moreover, the special relationship between the perpetrator and the victim itself do not facilitate the discovery and prosecution of the perpetrators under Art. 207 of the k.k as these persons most often are in permanent family relationships or relationships of dependence (e.g. employer-employee), which conditions make victims of abuse reluctant to report crimes (Art. $304 \$ 1$ of the Act of 6 June 1997 Code of Criminal Procedure, hereinafter also referred to as „k.p.k.”). Even if proceedings in such cases are initiated ex officio, victims do not always cooperate with 
law enforcement agencies as they are often forced to keep contact with suspects or even live with them afterwards.

Due to the above-mentioned difficulties and the need to strengthen the legal position of the victim of domestic violence, the legislator has decided to issue a separate act to regulate these issues. According to the Explanatory Statement of the Bill on Counteracting Domestic Violence, this Act was to be based on the following assumptions: emphasizing the fact that domestic violence is a crime; responsibility of the state for preventing and punishing acts of domestic violence; responsibility of the perpetrators for the acts committed by them and the victims' right to safety (cf. Explanatory Statement of the Bill on Counteracting Domestic Violence, Sejm paper No. 3639, Sejm of the $4^{\text {th }}$ term, p. 6). To achieve the intended goals, the Act introduced, among other things, the definitions of domestic violence and family. The forms of assistance provided to a person affected by domestic violence (Article 3 of the u.p.p.r.) and limitations in contact between the perpetrator of violence and the victim (Article 5 of the u.p.p.r.) were also specified. Finally, the possibility of ordering the perpetrator to leave the premises was introduced (Art. 14 of the u.p.p.r.).

Then, the "Blue Cards" procedure was incorporated into the Act on Counteracting Domestic Violence under the Amendment of 10 June 2010. Therefore, it was anchored in a generally applicable legal act (initially, this procedure was standardized in the orders of the Police Commander in Chief, i.e. domestic law, cf. e.g. the Order no. 25/98 of the Police Commander in Chief of 10 November 1998 on the manner of conducting domestic interventions against domestic violence by police officers under the name of "Blue Cards" (for more information on the creation of this procedure see Wrona, 2017, p. 81 et al.). The newly added Art. 9d para. 1 of the u.p.p.r. stipulated that interventions concerning a family affected by violence were to be based on the "Blue Cards" procedure. At the same time, Art. 9d para. 5 incorporated an authorization for the Council of Ministers to issue an ordinance to specify this procedure and prepare appropriate specimen forms. Pursuant to the above-mentioned statutory authorization, the Ordinance of the Council of Ministers of 13 September 2011 regarding the "Blue Cards" procedure and "Blue Card" forms was issued (hereinafter also referred to as the "Ordinance") (for any doubts about the above authorization see Spurek, 2012, p. 148).

To conclude, it should be pointed out that the phenomenon of domestic violence itself is of an interdisciplinary character and can thus be analysed from various angles, that is, from the point of view of different sciences, namely sociology, pedagogy or other. Nevertheless, the subject of this article is a legal analysis and therefore, the choice of research methods also requires some comments. Due to the fact that the current legal solutions constitute the subject of the research, the 
dogmatic-legal method has been applied as basic, consisting in a juridical analysis of relevant legal provisions. The study of legal texts has been complemented where appropriate by presenting the views of doctrine and judicature. Moreover, the historical-legal theoretical-legal methods have also been used to a lesser extent.

\section{Definitions of domestic violence and family member}

As indicated in literature, the intentionality, asymmetry and the resulting infringement of personal rights and interests of immediate family members constitute, in general terms, the characteristics of domestic violence (cf. Alagierska, 2012, p. 9; Mróz, 2013, pp. 8-9). Nevertheless, the Act on Counteracting Domestic Violence introduced its own legal definition of domestic violence. It was included in Art. 2 point 2 of the u.p.p.r, which also refers to Art. 2 point 1 of the u.p.p.r and Art. $115 \$ 11$ of the k.k. regarding the notion of family. According to these provisions, whenever the Act refers to domestic violence, it should be understood as a non-recurrent or recurrent intentional act or omission that infringes the personal rights and interests of a spouse, ascendants or descendants, siblings, persons related through marriage in the same line or degree of kinship, relatives under adoption and their spouse, cohabitants or persons living in, or running the same household, in particular that expose them to danger of loss of life, health, infringe their dignity, bodily inviolability, freedom, including sexual freedom, cause damage to their physical or mental health and also suffering and moral harm (Art. 2 point 2 of the u.p.p.r. in connection with Art. 2 point 2 of the u.p.p.r and Art. $115 \$ 11$ of the k.k.). Reasonable suspicion of such acts being committed enables the commencement and conduct of the "Blue Cards" procedure.

It should be pointed out implicitly that to fulfil this definition of domestic violence - unlike in the case of the crime of abuse - at least one act with the features specified in Art. 2 point 2 of the u.p.p.r. is sufficient. Still, these could also be recurrent acts bearing the attributes of violence only through certain regularity or frequency. The legislator, however, requires that such an act or acts must be committed intentionally. Yet, the latter concept is not defined under the u.p.p.r. It appears, though, that in this respect it is possible to refer to the provisions of the Criminal Code that regulate intention (such a view may be supported by a similar formulation of both Acts in mentioning ,intention” and not intentional fault; moreover, an explicit reference is made to the provisions of the Criminal Code with regard to the concept of family, which also indicates a close relationship between the Act on Counteracting Domestic Violence and this codification). The above issue is regulated by Art. $9 \$ 1$ of the Criminal Code, according to which the prohibited act is 
committed intentionally if the perpetrator intends to commit it, that is, he or she wants to commit it, or consents to it by foreseeing the possibility of committing it, whereas, in accordance with the principle of lege non distinguente, the possibility that such an act could be committed with both direct intent or recklessness should be allowed.

It should also be noted that although the perpetrator's behaviour can take the form of both action (e.g. pushing, slapping) and inaction (e.g. ignoring), most often, still, this would be an action. Such behaviour may be classified as domestic violence if it infringes the personal rights or interests of persons mentioned in Art. 2 point 1 of the u.p.p.r., in particular exposing them to danger of loss of life, health, infringing their dignity, bodily inviolability, freedom, including sexual freedom, causing damage to their physical or mental health, and causing suffering and moral harm. In practice, therefore, specific acts representing domestic violence may at the same time bear the attributes of crimes, e.g. homicide (Article 148 of the k.k.), rape (Article 197 of the k.k.), robbery (Article 280 of the k.k.), unlawful termination of pregnancy (Article 153 of the k.k.), abuse (Art. 207 of the k.k.), defamation (Art. 212 of the k.k.), insult (Art. 216 of the k.k.) or infringement of bodily inviolability (Art. 217 of k.k.). In such cases, the legislator imposes a special obligation on persons who, in connection with the performance of their official or professional duties, suspect a crime involving domestic violence that is prosecuted ex officio has been committed. They are obliged to immediately notify the police or the prosecutor of this fact (Article 12 para. 1 of the u.p.p.r.). Persons who witness domestic violence also have a similar obligation. They should notify of such situations the police, the prosecutor or another entity acting to counteract domestic violence (Art. 12 para. 2 of the u.p.p.r).

The actions of the perpetrator of domestic violence in a given case may, but do not have to simultaneously constitute crimes. The above follows from the fact that the Act on Counteracting Domestic Violence introduces its own definition of domestic violence ("whenever the Act mentions domestic violence it should be understood as [...]") that is independent of other prohibited acts. Moreover, the catalogue of behaviours which may constitute domestic violence is an open and exemplary one as evidenced by the statutory phrase „specifically” in Art. 2 point 2 of the u.p.p.r. This is the proper approach, as it is impossible to name all cases of domestic violence a prior. However, the "Blue Card" - D form which constitutes an appendix to the „Blue Cards” procedure lists some (seemingly typical) forms of domestic violence. The following have been indicated concerning physical violence: pushing, hitting, twisting arms, strangling, kicking, slapping, including causing bruising, scratching, bleeding and burns. With regard to psychological violence, the following actions have been listed expressis verbis: isolating, name-calling, 
ridiculing, threatening, controlling, limiting contacts, criticizing, humiliating, demoralizing and constantly disturbing. Sexual violence, including forced sexual intercourse or other sexual activities, is mentioned separately. Interestingly, this form also provides for the damage or destruction of property, which may affect immediate family members only indirectly.

Whether economic violence may also be considered domestic violence requires a separate consideration. The definition of domestic violence does not mention this form of violence verba legis, but it does not have as the catalogue of acts is open. It should be noted, however, that economic violence is referred to in the Convention on preventing and combating violence against women and domestic violence, opened for signature on 11 May 2011 in Istanbul, (hereinafter referred to as "the Convention"), which has been ratified - with some exceptions - by Poland (cf. the Act of 6 February 2015 on ratification of the Council of Europe Convention on preventing and combating violence against women and domestic violence opened for signature on 11 May 2011 in Istanbul). This Convention defines domestic violence as any act of physical, sexual, psychological or economic violence occurring within a family or household, or between former or present spouses or partners, whether or not the perpetrator and victim share or have shared the place of residence (Art. 3(b) of the Convention). Thus, economic violence is clearly mentioned therein and this fact was accepted by the Polish legislator through the act of ratification. As a consequence, it can be assumed that, by incorporating the Convention into the Polish legal system, the legislator also allowed for the possibility of protecting victims against such acts. Therefore, there are no reasons for excluding economic violence from the definition of domestic violence, as long as it meets the conditions set out in Art. 2 point 2 of the u.p.p.r.

In this context, it should be added that there may be practical problems in determining cases concern economic violence. No legal definition exists and the above convention only mentions such a form of violence without any further specification. In literature, this issue is treated in various ways. As an example, it could be said that economic violence occurs "when the perpetrator uses money or other tangible assets to meet the need to maintain power and control over their partner, or transfers the responsibility for maintaining the household to him or her. The perpetrator uses the partner's dependence on his or her income or assets to abuse them (Tracz-Dal, 2015, p. 3). M. Zając, on the other hand, defines this concept as „all action aimed at the total financial dependence of the victim on the perpetrator by forbidding them to undertake gainful employment, obstructing professional activity and making them remain entirely dependent on ["and at the mercy of»] the partner or legal guardian" (Zając, 2012, pp. 18-19; regarding economic violence cf. Ksieniewicz, 2013, pp. 43 et al.). 
Our analysis of the definition of domestic violence shall be concluded with the subjective aspects. The legislator clearly indicates that this regulation does not just pertain to any kind of violence, but specifically to violence in the family. From this point of view, it is important between whom the acts of violence take place. A catalogue of persons is provided in Art. 2 point 1 of the u.p.p.r. and refers in part to Art. $115 \$ 11$ of the k.k. which defines immediate family member. Consequently, within the meaning of the above provisions, family members include the spouse, ascendants, descendants, siblings, persons related through marriage in the same line or degree of kinship, adopted persons and their spouses, cohabiting persons (Article $115 \$ 11$ of the Penal Code) and other people living together or running a household (Art. 2 point 1 of the Act).

\section{The "Blue Cards" procedure: legal nature and practical problems related to application}

The "Blue Cards" procedure constitutes a separate regulation which is governed by the Act on Counteracting Domestic Violence and the Ordinance of the Council of Ministers of 13 September 2011 regarding the "Blue Cards" procedure and the "Blue Card" forms issued thereuder. The procedure and manner of appointing and recalling members of the interdisciplinary team and specific functioning conditions should be specified in a resolution of competent commune council. Under these provisions, however, no general reference to criminal, civil or administrative procedures is made.

Nevertheless, due to the very entities that initiate and conduct the above-mentioned proceedings, it might seem that this is actually a special type of administrative procedure, and as a consequence, the suspect could be entitled to legal remedies provided for in the Act of 14 June 1960 - The Code of Administrative Proceedings, hereinafter also referred to as „k.p.a.”, and the Law on Proceedings Before Administrative Courts (the Act of 30 August 2002 - Law on Proceedings Before Administrative Courts, hereinafter also referred to as „p.p.s.a.”). Since the Act on Counteracting Domestic Violence came into force, the court jurisprudence has held the position that activities undertaken by the interdisciplinary team cannot be subject to judicial and administrative control, including under Art. $3 \$ 2$ point 4 of the p.p.s.a. (cf. the Decision of the Supreme Administrative Court of 25 November 2015, case No. I OSK 2896/15; the Decision of the Voivodship Administrative Court in Bydgoszcz of 8 May 2015, case No. II SA/ Bd 376/15; cf. also the Decision of the Voivodship Administrative Court in Gorzów Wielkopolski 13 December 2013, case No. II SA/Go 883/13; Judgment of 
the Voivodship Administrative Court in Wrocław of 14 October 2014, case No. IV SAB/Wr 166/14).

In the judicature, it has generally been assumed that the interdisciplinary team is not a public administration body, neither in the systemic nor in the functional sense (in other words, the Decision of the Supreme Administrative Court of 25 November 2015, case No. I OSK 2896/15 which assumes it is an administrative body in the functional sense, but its activities are not subject to the jurisdiction of administrative courts), as it does not have any powers of authority, in particular the right to issue administrative decisions, orders or other acts or actions regarding the rights or obligations resulting from the law. All activities undertaken by the interdisciplinary team belong to the sphere of non-regulatory legal actions. They do not aim directly at producing legal effects and cannot be implemented by means of direct coercion. The above Decision of the Supreme Administrative Court of 25 November 2015 emphasizes that ,the analysis of the competences entrusted to the interdisciplinary team [...] shows that these are limited only to integration, coordination and organization of the cooperation of entities listed by the legislator" (the decision of the Supreme Administrative Court of 25 November 2015, case No. I OSK 2896/15).

In the most recent court and administrative jurisprudence, though, this wellestablished approach has been questioned. Namely, the Decision of the Voivodship Administrative Court in Poznań of 14 June 2017 states expressis verbis that "actions undertaken by the interdisciplinary team (or lack thereof) relating to the rights or obligations of participants in these proceedings arising from provisions of the law may be subject to judicial and administrative control since these constitute the activities referred to in Art. $3 \$ 2$ point 4 of the Law on Proceedings Before Administrative Courts. There are no obstacles for a party to subject to judicial and administrative control the activities of the interdisciplinary team for the completion of the "Blue Cards" procedure (the Decision of the Voivodship Administrative Court in Poznań of 14 June 2017, case No. II SAB/Po 87/17)”.

In that decision, it has been pointed out that, according to the provisions of the u.p.p.r., "a person affected by domestic violence [...] has a number of rights under the "Blue Cards" procedure, depending on case status. According to Art. 3 para. 1 of the u.p.p.r. such person is provided with free assistance, including, 1) medical, psychological, legal, social, professional and family counselling; 2) crisis intervention and support; 3) protection against further harm by preventing persons exercising violence from using apartments occupied jointly with other family members and forbidding contact with, or approaching the victim; 4) providing a person affected by domestic violence with a safe shelter in a specialized support center for victims of domestic violence; 5) medical examination to determine the causes and 
type of bodily injuries related to the use of domestic violence and issuing a relevant medical certificate; 6) providing a person affected by domestic violence who does not have a legal title to the apartment occupied jointly with the perpetrator of violence with assistance in obtaining one. This view is also assumed by M. Czarkowska who points out that "both interdisciplinary teams and working groups have specific obligations under the "Blue Cards" procedure defined, inter alia, in $\$ 16$ para. 1 of the Ordinance" (cf. Czarkowska, 2014, p. 106).

Next, it should be pointed out that in accordance with Art. 9d para. 2 of the u.p.p.r. the "Blue Cards" procedure covers all activities undertaken and carried out by representatives of social assistance organizational units, commune commissions for solving alcohol problems, police and educational and health authorities in connection with a reasonable suspicion of domestic violence. At this point, we should emphasise that in order to initiate this procedure, it is not necessary to prove the use of violence, but only to substantiate that it is used. As sometimes indicated in literature, the initiation may even take place when "there is a suspicion of the use of violence, even when it is not supported by any evidence or circumstances" (Wrona, 2011, p. 9). Taking into account the linguistic interpretation, however, it is difficult to assume that, in the latter case, we are still dealing with a "reasonable suspicion of the use of violence" as there are no circumstances or evidence to support it. The procedure is formally initiated with the completion of the "Blue Card - A form" and further steps are taken before the interdisciplinary team referred to in Art. 9a of the u.p.p.r.

As far as practical problems related to the application of this procedure are concerned, it should be noted that due to an extremely wide subjective scope of acts which may constitute domestic violence within the meaning of Art. 2 point 2 of the u.p.p.r. and the fact that to initiate the „Blue Cards” procedure only a reasonable suspicion is sufficient, this regulation may be used instrumentally by conflicted immediate family members. It is not rare for trial representatives to advise a party to initiate the „Blue Cards” procedure to present the opposing party in a negative light in court proceedings before a divorce petition is filed.

However, irregularities do not necessarily have to result from the intentional action of a family member or their legal representative. These may also be caused by incorrect actions of officers cooperating in the implementation of the „Blue Cards” procedure or members of the interdisciplinary team themselves. Such errors may be manifested, for example, initiating the procedure despite the lack of a reasonable suspicion of domestic violence, lack of intent on the part of the perpetrator, incorrect filling of the „Blue Cards” or failure to complete the procedure despite the cessation of acts of violence.

In such cases, a person suspected of using domestic violence will have a limited ability to defend their rights. In principle, they will be heard only during the meet- 
ing of the interdisciplinary team and for this purpose, the „Blue Card - D” form will be completed. Nevertheless, as a rule, the possibility of defending a person suspected of using domestic violence will appear in other proceedings. In particular, if the alleged act constituting domestic violence is also considered a crime, in the pending criminal proceedings the suspect could use various defence measures (e.g. providing evidence, including in particular interrogation of the parties or intervening police officers or a possible confrontation). In practice, however, it will not always be possible due to the fact that not every act of domestic violence constitutes a crime.

Ultimately, if the „Blue Cards” procedure is initiated and carried out as a result of an unjustified or false notification of domestic violence, and this allegation could not be verified otherwise, the suspect would be entitled to an action for the protection of personal rights (cf. Art. 23 and 24 of the Act of 23 April 1964 - Civil Code, hereinafter also referred to as „k.c.”), in particular, on the basis of damage to reputation, honour or dignity. Regardless of the above, it would also be possible to file a private indictment based on a charge of defamation (Article 212 of the k.k.).

\section{Conclusions}

The "Blue Cards" procedure constitutes a significant element of the domestic violence prevention system. It was introduced into Polish law because the existing protection under the criminal law was believed to be insufficient in situations where violence was used by an immediate family member, often living with the victim. Another disadvantage of criminal proceedings was the fact that they usually took time, meanwhile the perpetrator could use the presumption of innocence until conviction by a final judgement.

In view of the above difficulties, the legislator has decided to introduce a completely new "Blue Cards" procedure applicable to families affected by violence. The legal nature thereof, however, raises certain doubts. Definitely not a type of criminal or civil, but rather a special type of administrative procedure, or, in any case, most closely corresponding to it.

This legal nature of the "Blue Cards" procedure has both positive and negative sides. One positive aspect, above all, is that it can be faster, and thus make it possible to counteract domestic violence more quickly. On the negative side, persons suspected of using domestic violence have limited possibilities to defend themselves in such proceedings. Due to the similarity between the "Blue Cards" procedure and administrative proceedings, a suspect of domestic violence will not enjoy the presumption of innocence or the right to submit evidence. In fact, they 
do not even have effective means of appealing to verify the actions and decisions made in the course thereof. The administrative case law generally assumes that in such cases there is no right to lodge a complaint with a voivodeship administrative court. The judicature justifies this position by the fact that the interdisciplinary team, before which this procedure is pending, is not a public administration body. Consequently, it does not take authoritative decisions, and therefore its actions cannot be classified as acts or activities within the scope of public administration concerning rights or obligations resulting from legal provisions within the meaning of Art. $3 \$ 2$ point 4 of the p.p.s.a. This circumstance is important as the very initiation of the "Blue Cards" procedure against a person suspected of using domestic violence is particularly negatively perceived by the society.

In view of the above, the defence of the rights of a person suspected of using domestic violence, if possible in a given case, must be based on other legal regulations. This fact is acknowledged by the Supreme Administrative Court in pointing out that the inability to lodge a complaint in administrative court proceedings "does not deprive (...) the applicant of the right to due process. The rights and obligations of the complainant will be regulated within the framework of proceedings governed by separate acts (...). In each of these proceedings, the complainant will enjoy the right to defence" (the decision of the Supreme Administrative Court of 25 November 2015, case No. I OSK 2896/15).

Certain doubts are also raised by the definition of family member used to determine whether domestic violence is being dealt with, which is a condition for initiating the procedure in question. The catalogue of entities listed in Art. $115 \$$ 11 of the k.k. in connection with Art. 2 point 1 of the u.p.p.r. does not cause any concerns as it includes people related by kinship or affinity or cohabiting (e.g. cohabitants). Yet, indicating directly in the Act on Counteracting Domestic Violence that family members also include other household members or people running a household together may raise certain questions. In practice, these people may not be bound by any legal or family relationship or even cohabitation, but live or run a household together for factual reasons (e.g. students in a dormitory or lodgings). Including them among family members seems to stray too far from the common understanding of family and is not sufficiently justified by ratio legis (cf. Dudka, 2006, p. 44; Kiełtyka and Ważny, 2015, p. 37). For in such cases, none of the specific difficulties occur that gave rise to the introduction of the Act on Counteracting Domestic Violence (e.g. the existence of an emotional bond or the necessity to live together) and the "Blue Cards" procedure. 


\section{References}

Act of 10 June 2010 amending the Act on Counteracting Domestic Violence and Other Acts (Journal of Laws of the Republic of Poland 2010, No. 125, item 842).

Act of 14 June 1960 - The Code of Administrative Proceedings (consolidated text: Journal of Laws of the Republic of Poland 2020, item 256).

Act of 23 April 1964 - The Civil Code (consolidated text: Journal of Laws of the Republic of Poland 2020, item 1740).

Act of 23 March 2017 amending the Criminal Code, the Act on Juvenile Delinquency Proceedings and the Code of Criminal Procedure (Journal of Laws of the Republic of Poland 2017, item 773).

Act of 29 July 2005 on Counteracting Domestic Violence (consolidated text: Journal of Laws of the Republic of Poland 2020, item 218).

Act of 30 August 2002 - Law on Proceedings Before Administrative Courts (consolidated text: Journal of Laws of the Republic of Poland 2019, item 2325).

Act of 6 February 2015 on ratification of the Council of Europe Convention on preventing and combating violence against women and domestic violence (Journal of Laws of the Republic of Poland 2015, item 398).

Act of 6 June 1997 - the Code of Criminal Procedure (consolidated text: Journal of Laws of the Republic of Poland 2020, item 30).

Act of 6 June 1997 - The Criminal Code (consolidated text: Journal of Laws of the Republic of Poland 2020, item 1444).

Alagierska L. (2012). Procedura "Niebieskie Karty” w praktyce. Wrocław: Grupa Ergo sp. z o.o.

Council of Europe Convention on preventing and combating violence against women and domestic violence, opened for signature on 11 May 2011 in Istanbul, Turkey.

Czarkowska M. (2014). Przeciwdziatanie przemocy wobec kobiet $w$ rodzinie $w$ praktyce organów ścigania, wymiaru sprawiedliwości i innych instytucji. Warszawa: LexisNexis.

Decision of the Supreme Administrative Court of 25 November 2015, case No. I OSK 2896/15, Legalis 1386921.

Decision of the Supreme Court of 23 May 2017, case No. III KK 157/17, Legalis 1657909.

Decision of the Voivodship Administrative Court in Bydgoszcz of 8 May 2015, case No. II SA/Bd 376/15, Legalis 127756.

Decision of the Voivodship Administrative Court in Gorzów Wielkopolski 13 December 2013, case No. II SA/Go 883/13, Legalis 947518. 
Decision of the Voivodship Administrative Court in Poznań of 14 June 2017, case No. II SAB/Po 87/17, Legalis 1654118.

Dudka K. (2006). Środki zapobiegawcze stosowane wobec sprawców przemocy w rodzinie, „Wojskowy Przegląd Prawniczy” 2.

Explanatory Statement of the Bill on Counteracting Domestic Violence, Sejm paper No. 3639, Sejm of the $4^{\text {th }}$ term.

Judgment of the Appeal Court in Kraków of 20 March 2012, case No. II AKa 32/12, Legalis 527938.

Judgment of the Supreme Court of 11 February 2003, case No. IV KKN 312/99, Legalis 58692.

Judgment of the Supreme Court of 13 September 2005, case No. WA 24/05, Legalis 140676 .

Judgment of the Supreme Court of 21 October 1999, case No. V KKN 580/97, Legalis 46281.

Judgment of the Supreme Court of 8 February 1982, case No. II KR 5/82, Legalis 22971.

Judgment of the Voivodship Administrative Court in Wrocław of 14 October 2014, case No. IV SAB/Wr 166/14, Legalis 1195181.

Kiełtyka A., Ważny A. (2015). Przeciwdziatanie przemocy w rodzinie. Komentarz. Warszawa: Wolters Kluwer.

Mazowiecka L. (red.) (2013). Jak skutecznie chronić ofiary przemocy $w$ rodzinie. Warszawa: Wolters Kluwer.

Mróz D. (2013). Praktyczne rozwiązania realizacji Procedury „Niebieskie Karty”. Warszawa: Drukarnia Dimograf sp. z o.o.

Order No. 25/98 of the Police Commander in Chief of 10 November 1998 on the manner of conducting domestic interventions against domestic violence by police officers under the name of „Blue Cards” (Journal of Laws of the General Headquarters of Police no. 7, item 37).

Ordinance of the Council of Ministers of 13 September 2011 r. regarding the "Blue Cards" procedure and "Blue Card" forms (Journal of Laws of the Republic of Poland 2011 No. 209, item 1245).

Sosnowska J.D. (2008). Przestępstwo znęcania się. „Państwo i Prawo” 3, 60-71.

Spurek S. (2012). Przeciwdziatanie przemocy $w$ rodzinie. Komentarz. Warszawa: Wolters Kluwer.

Tracz-Dal J. (2015). Przemoc ekonomiczna. Warszawa: Kancelaria Senatu.

Wrona G. (2011). Rozporządzenie Rady Ministrów w sprawie procedury Niebieskie Karty. Komentarz. Warszawa: Ośrodek Informacji Prawnej Grzegorz Wrona.

Wrona G. (2017). Konflikt a przemoc. Zastosowanie art. 207 \$ 1 k.k. w przeciwdziataniu przemocy w rodzinie. Warszawa: Pracownia Poligraficzna „Duet”. 
Zając M. (2012). Procedura „Niebieskie Karty”. Realizacja zadań w zakresie przeciwdziatania przemocy $w$ rodzinie. Wrocław: Presscom sp. z o.o.

Przepisy prawa polskiego dotyczące podejmowania interwencji wobec rodziny dotkniętej przemocą - procedura „Niebieskie Karty”, jej charakter prawny i praktyczne problemy związane $z$ jej stosowaniem

\section{Streszczenie}

Przedmiotem artykułu jest analiza przepisów procedury „Niebieskie Karty”, inicjowanej w przypadku powzięcia informacji o stosowaniu przemocy w rodzinie. $\mathrm{Na}$ wstępie przedstawiono genezę wprowadzenia tej regulacji na grunt ustawy o przeciwdziałaniu przemocy w rodzinie. W dalszej kolejności przybliżono normatywną definicję przemocy w rodzinie i członka rodziny oraz problemy związane z ich praktycznym stosowaniem. W kolejnych częściach przedstawiono charakter prawny procedury „Niebieskie Karty”, jej przebieg oraz kroki prawne jakie może podejmować osoba podejrzana o stosowanie takiej przemocy oraz członkowie rodziny dotknięci taką przemocą.

Słowa kluczowe: przemoc, przemoc w rodzinie, procedura „Niebieskie Karty” 